\title{
Vascular Endothelial Growth Factor in the Human Diaphragm: New Insight into Adaptation Mechanisms in Chronic Obstructive Pulmonary Disease Patients
}

\author{
Andrea Zanini ${ }^{a}$ Alfredo Chetta ${ }^{b}$ \\ a Salvatore Maugeri Foundation, Division of Pneumology, IRCCS Rehabilitation Institute of Tradate, Tradate, and \\ ${ }^{b}$ Department of Clinical Sciences, Section of Respiratory Diseases, University of Parma, Parma, Italy
}

In chronic obstructive pulmonary disease (COPD), respiratory muscles work against increased mechanical loads due to airflow limitations and geometrical changes in the thorax derived from pulmonary hyperinflation [1]. The main respiratory muscle, the diaphragm, develops structural adaptations consisting of shifting from type II to type I fibers and increasing mitochondrial density [24]. It is also well known that a major adaptation of skeletal muscles to repeated exercise (endurance training) is the formation of new capillaries $[5,6]$. The respiratory muscles are skeletal muscles and respond to endurance training by increasing their capillary density, as do the locomotive muscles [7].

With respect to the locomotive skeletal muscles, the diaphragm is characterized by continual and rhythmical contraction, and thus is subjected to lifelong 'endurance training'. Since respiratory muscle failure is a life-threatening condition, it is important to understand the regulation of capillary growth in respiratory muscles.

Recently, in an animal model, Siafakas et al. [8] showed that active increases in ventilation by hypoxia and/or hypercapnia upregulate vascular endothelial growth factor (VEGF) and basic fibroblast growth factor (bFGF) messenger ribonucleic acid (mRNA) levels in the diaphragm, and this increase is proportional to minute ventilation. A remarkable contribution to support a possible role of VEGF in the structural adaptation of the human dia- phragm in patients with COPD is given by Alexopoulou et al. [9] in their paper published in this issue of Respiration. In this study, including moderate COPD patients, obese patients and healthy controls, the authors investigated VEGF, bFGF and transforming growth factor $\beta_{1}$ $\left(\mathrm{TGF} \beta_{1}\right)$ mRNA levels in diaphragm specimens from their subjects.

The results show that mRNA for VEGF, bFGF and TGF $\beta_{1}$ was detected in the diaphragms of every patient. In particular, the levels of VEGF mRNA were significantly higher in COPD patients than in control subjects. Moreover, as compared to control subjects, the levels of $\mathrm{TGF} \beta_{1}$ mRNA were higher in COPD patients while the levels of bFGF mRNA were higher in obese subjects, though the difference was not statistically significant. Taken together, these findings suggest that changes in lung mechanics can upregulate VEGF gene expression in the human diaphragm. Importantly, the study by Alexopoulou et al. [9] provides the first evidence in humans of the key role of VEGF in adaptation mechanisms of respiratory muscles, such as the diaphragm.

For a better understanding of the contribution of VEGF to adaptation mechanisms of the diaphragm, further studies are needed to evaluate relationships with clinical and functional data, in particular, disease severity, exercise capacity and breathlessness perception.

\section{KARGER}

Fax +4161306 1234 E-Mail karger@karger.ch www.karger.com
(C) 2005 S. Karger AG, Basel

0025-7931/05/0726-0577\$22.00/0

Accessible online at: www.karger.com/res
Dr. Andrea Zanini

Divisione Pneumologica, Fondazione Salvatore Maugeri

Clinica del Lavoro e della Riabilitazione, Via Roncaccio, 16

IT-21049 Tradate (Italy)

Tel. +390331829 111, Fax +390331829 417, E-Mail azanini@fsm.it 


\section{References}

1 Orozco-Levi M: Structure and function of the respiratory muscles in patients with COPD: impairment or adaptation? Eur Respir J Suppl 2003;46:41s-51s.

2 Levine S, Kaiser L, Leferovich J, Tikunov B: Cellular adaptations in the diaphragm in chronic obstructive pulmonary disease. N Engl J Med 1997;337:1799-1806.

3 Ribera F, N'Guessan B, Zoll J, Fortin D, Serrurier B, Mettauer B, Bigard X, Ventura-Clapier R, Lampert E: Mitochondrial electron transport chain function is enhanced in inspiratory muscles of patients with chronic obstructive pulmonary disease. Am J Respir Crit Care Med 2003;167:873-879.
4 Ramirez-Sarmiento A, Orozco-Levi M, Güell R, Barreiro E, Hernandez N, Mota S, Sangenis M, Broquetas JM, Gea J: Inspiratory muscle training in patients with chronic obstructive pulmonary disease: structural adaptation and physiologic outcomes. Am J Respir Crit Care Med 2002;166:1491-1497.

5 Brodal P, Ingjer F, Hermansen L: Capillary supply of skeletal muscle fibres in untrained and endurance-trained men. Am J Physiol 1977;232:H705-H712.

6 Jensen L, Bangsbo J, Hellsten Y: Effect of high intensity training on capillarization and presence of angiogenic factors in human skeletal muscle. J Physiol 2004;557:571-582.
7 Powers SK, Criswell D, Lieu FK, Dodd S, Silverman $\mathrm{H}$ : Exercise-induced cellular alterations in the diaphragm. Am J Physiol 1992; 263:R1093-R1098.

8 Siafakas NM, Jordan M, Wagner H, Breen EC, Benoit H, Wagner PD: Diaphragmatic angiogenic growth factor mRNA responses to increased ventilation caused by hypoxia and hypercapnia. Eur Respir J 2001;17:681-687.

9 Alexopoulou C, Mitrouska I, Arvanitis D, Tzanakis N, Chalkiadakis G, Melissas J, Zervou M, Siafakas N: Vascular-specific growth factor mRNA levels in the human diaphragm. Respiration 2005;72:636-641. 